\title{
Article
}

\author{
마이크로네시아 축 환초내 잘피밭의 어류 종조성 \\ 최영웅 · 윤건탁 · 이대원 · 김태훈 · 김윤칠 · 박흥식* \\ 한국해양과학기술원 태평양해양연구센터 \\ (426-744) 경기도 안산시 상록구 해안로 787
}

\section{Species Composition of Fish from Sea Grass Bed in Chuuk Lagoon, Micronesia}

\author{
Young-Ung Choi, Kon-Tak Yoon, Dae-Won Lee, Taihun Kim, Yoonchil Kim, and Heung-Sik Park* \\ Pacific Ocean Research Center, KIOST \\ Ansan 426-744, Korea
}

\begin{abstract}
The fish species composition of seagrass bed in Chuuk Lagoon, Micronesia, was investigated every month from August 2009 to July 2011, using a seine net for fish caught. A total of 32 fish species belonging to 18 families under 6 orders were identified during the study period. Of these fish, Atherinomrus lacunosus, and Strongylura incise were the major dominant species representing $85.0 \%$ in total number of individuals. The number of species and individuals were high from August to December 2009, 2010. The biomass was highest in September 2010 and the diversity index was higher in September 2009, April, August 2010 and July 2011. The 14 dominant species could be divided into 2 groups of 3 individuals based on appearance patterns; (1) resident species and temporal species ( 9 species, e.g. Atherinomrus lacunosus), juvenile and adults living in seagrass beds and juveniles living only in seagrass beds; (2) temporal species (2 species, e.g. Hemiramphus lutkei), juveniles living only in seagrass beds; (3) temporal species (3 individuals, e.g. Caranx sexfasiatus). For some species, the appearance patterns were affected by water temperature. However, the relationships between sea currents, salinity, tide, and structure of fish assemblage remain unclear. Further studies that regularly monitor sea grass habitats are necessary to clearly understand the correlation between environmental factors and sea grass habitat use patterns in fish assemblages.
\end{abstract}

Key words : Micronesia, Chuuk Lagoon, fish species, sea grass bed

\section{1. 서 론}

열대연안해역은 대부분 잘피밭과 함께 산호초, 맹그로 브 군락이 혼합된 형태의 서식지 구조를 갖고 있으며, 이 들 서식지 사이에 생태적 연결성은 산호초 어류 생활사를 구명하는데 중요하게 다루어져 왔다(Parrish 1989). 현재 산호초 어류 생태학에서 주요 논점 중 하나는 다양성을

*Corresponding author. E-mail : hspark@kiost.ac
유지하는데 서식지의 역할, 그리고 산호초 어류들이 잘피 와 맹그로브 서식지 이용 패턴을 이해하는 것이다 (Nakamura and Tsuchiya 2008). 산호초 어류들의 서식지 이용패턴을 추정하는 것은 열대 연안 생태계 시스템에서 생물학적 연결성을 이해하는데 필수적이고, 연안 어류 다 양성과 어류자원의 효율적 관리를 위해서도 기본적으로 요구되고 있다(Adams et al. 2006).

열대연안 서식지 중 하나인 잘피밭은 생물다양성이 높 은 곳 중에 하나로서 잘피 생활사단계에 따라 생성되는 
유기퇴적물과 용존유기물이 잘피의 엽상체에 부착하는 여 과식자, 많은 무척추동물의 좋은 먹이가 된다(Stoner 1980; Livingstone 1984; Thayer et al. 1984). 그리고 잘피 군락은 파랑의 세력을 약화시켜 안정된 환경을 만들고, 많 은 어류들이 포식자로부터 피할 수 있는 은신처를 제공하 며, 치어들의 보육장으로 역할을 한다(Bell and Pollard, 1989; Guidetti and Bussotti 2002; Klumpp et al. 1992). 지금까지 잘피밭 생태계 연구는 1980년대 이후부터 미국, 오스트레일리아, 유럽, 일본 그리고 우리나라를 중심으로 온대지역의 잘피밭을 대상으로 진행되어 왔다. 그러나 열 대 지역의 잘피밭 생태계에 관한 연구는 오스트레일리아 퀸즈랜드 지역에서 어류치어 보육장으로서 역할이 일부 조명되었을 뿐(Kwak and Klumpp 2004), 이외의 정보는 거의 없는 실정이다.

마이크로네시아에서 잘피밭은 산호초, 맹그로브 군락과
함께 해양생물의 주요 서식지 중 한 곳으로 각종 어류와 무척추 동물이 서식하여 현지인들의 기초 생계형 어업이 행해지는 장소이다. 최근 마이크로네시아 연안해역에서는 현지인들의 기초 생계형 어업이 상업적 규모로 변화되어 일부 종이 남획에 이르게 됨에 따라 잘피밭에 서식하는 생물자원 관리 필요성을 인식하기 시작하였다. 그러나 안 정적 자원관리를 위한 서식 어류상에 대한 정보는 찾아보 기 힘들다.

이 연구에서는 축 라군내 잘피밭에서 월별로 어류를 채 집하여 출현어류 종조성 조사결과를 보고한다.

\section{2. 재료 및 방법}

조사지역은 마이크로네시아 축 환초(Chuuk Atoll) 내 웨노섬(Weno Island) 북동부 연안 베네딕 리프(Benedict

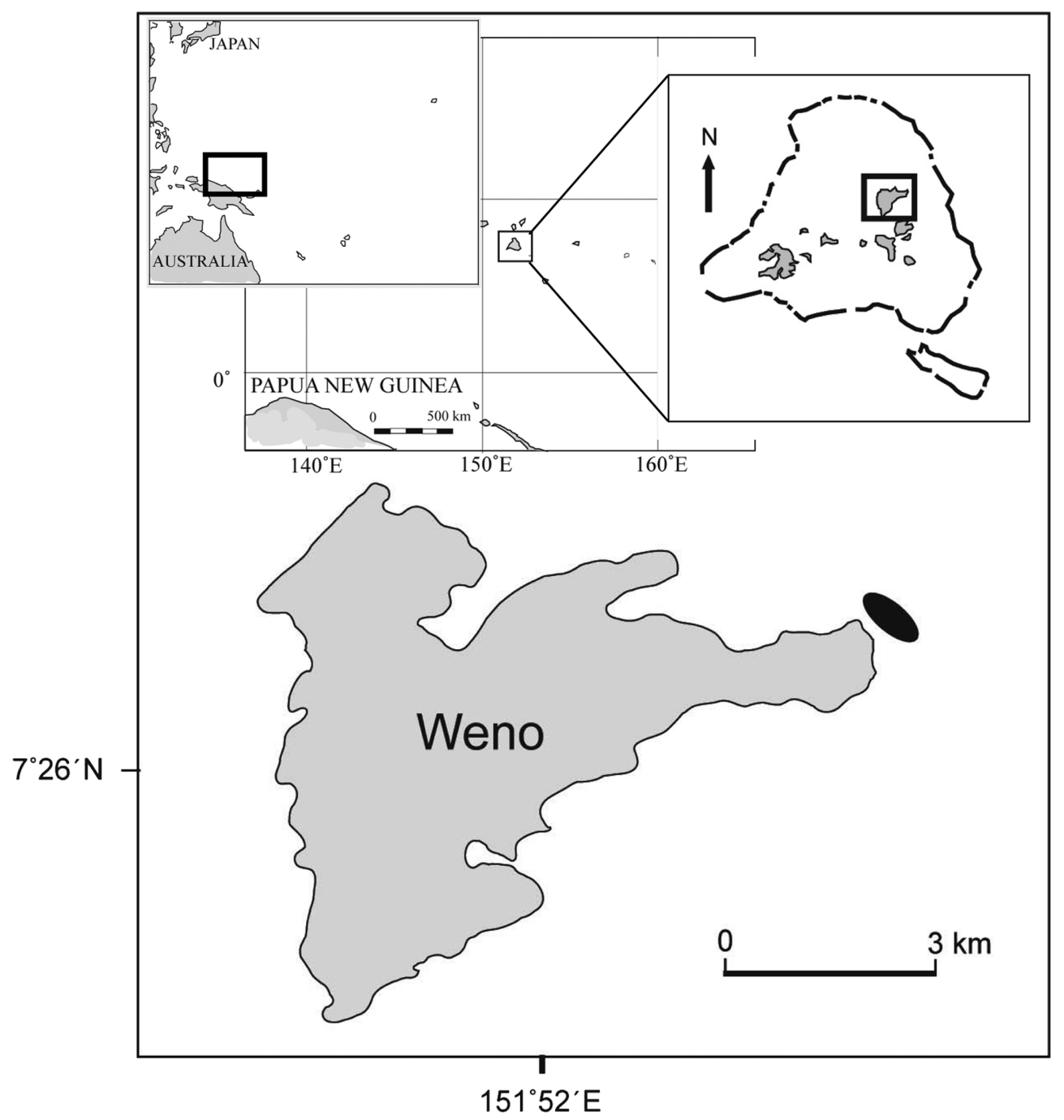

Fig. 1. Map showing the sampling site in Weno Island of Chuuk Lagoon, Micronesia. The black dot indicated the sampling area 
Reef)에 위치한 잘피밭 $\left(7^{\circ} 27^{\prime} \mathrm{N}, 151^{\circ} 54^{\prime} \mathrm{E}\right)$ (Fig. 1)이며 주 변환경은 환초로 둘러 쌓여 있어 파도가 약하고, 전방 수 백 $\mathrm{m}$ 까지는 수심 $1 \mathrm{~m}$ 내외이다. 그리고 잘피밭은 맹그로 브와 산호초 군락이 혼재하는 해안구조로 수심 깊이에 따라 이 둘 서식지 사이에 위치한다. 이 연구의 시료는 2009년 8월부터 2011년 7월까지 매월 25일에서 30일 사 이에 후릿그물(길이 $30 \mathrm{~m}$, 높이 $5 \mathrm{~m}$, 망목 $16 \mathrm{~mm}$ )를 사 용하여 채집하였다. 채집시 같은 장소가 반복되지 않도록 하면서 5회 투망하여 예인하였고, 1 회 예인시간은 5분이 었다. 조사기간 동안 수온은 SEACAT Profiler(SBE 19; Sea-Bird Electronics, Bellevue, WA)로 수심 $1 \mathrm{~m}$ 에서 측 정된 자료를 이용하였다. 그리고 강수량 자료는 National Oceanic and Atmospheric Administration (NOAA 2013) 의 자료를 이용하였다.

채집된 어류는 냉장 보관하여 실험실로 운반한 후, 체 장과 무게를 측정하였다. 종의 동정에는 Myers (1999)를 이용하였다. 어류의 월별 변동양상을 비교하기 위해 종 다 양도(Shannon and Wiener 1963) 지수를 아래식으로 구하 였다.

$$
\begin{aligned}
& \text { 종 다양도 지수 }(\text { diversity index }): \mathrm{H}^{\prime}=\Sigma \mathrm{P}_{\mathrm{i}} \times \ln \left(\mathrm{P}_{\mathrm{i}}\right) \\
& \mathrm{P}_{\mathrm{i}}: \text { i번째 종의 점유율 }
\end{aligned}
$$

출현종간 유사성을 분석하기 위해 출현개체수 자료를 근거로 Bray-Curtis 유사도 지수를 이용하여 집괴분석을
실시한 후 수상도를 작성하였고, 비계량형 다차원척도법 (nMDS, non-metric multi-dimensional scaling)을 실시하 였다. 그리고 출현종과 환경요인과의 관계를 분석하기 위 해 CCA(canonical correspondence analysis)를 수행하였다. 모든 통계분석은 3회 이상 출현한 종만을 대상으로 실시 하였다. 통계분석에서 집괴분석은 Primer Software 5.0 package, CCA에는 CANOCO Software 4.5 package를 이 용하였다.

\section{3. 결 과}

\section{환경}

마이크로네시아 축 라군내 잘피밭 주변 평균 수심 $1 \mathrm{~m}$ 층의 월별 평균수온 분포는 2010년 2월과 2011년 2월에 각각 $28.3,28.7^{\circ} \mathrm{C}$ 로 가장 낮았고, 2009 년 8월과 2010년 8 월에 각각 $29.5,29.7^{\circ} \mathrm{C}$ 로 최고치를 나타내었다. 그 외 조 사기간 동안 수온은 $28.5-29.5^{\circ} \mathrm{C}$ 범위를 유지하였다(Fig. 2).

월별 평균강수량은 2009년 9-11월에 424.7-531.6 mm 로 높은 수치를 나타내었으나 이후 증감을 반복하면서 하 강하기 시작하였고, 2010년 2월에 $62.5 \mathrm{~mm}$ 로 연중 최저 치를 기록하였다. 3 월 이후 증감을 반복하면서 증가하였 고, 8월에는 $575.1 \mathrm{~mm}$ 로 연중 최고치를 나타내었다. 이후 에는 2009-2010년과 비슷한 경향으로 감소하기 시작하였 고, 2011년 1월에 $205.2 \mathrm{~mm}$ 로 연중 최저치를 기록하였으

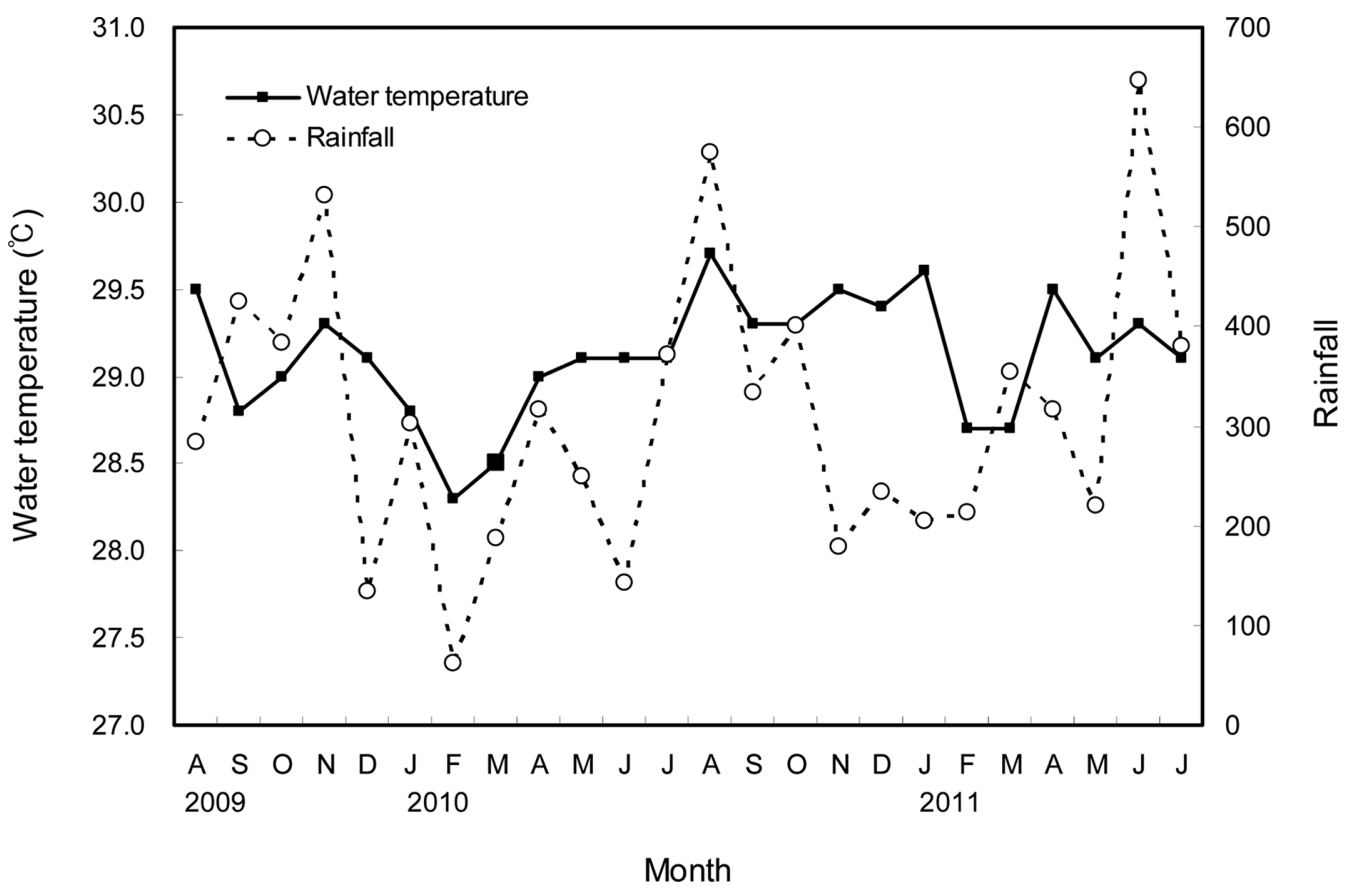

Fig. 2. Monthly variation of mean water temperature and rainfall in Chuuk Lagoon, Micronesia from August 2009 to July 2011 
며, 이후 증가하기 시작하여 6월에 $646.9 \mathrm{~mm}$ 로 조사기간 중 가장 많은 강수량을 기록하였다(Fig. 2).

\section{종조성}

조사기간 동안 총 6 목 18 과 32 종이 출현하였다. 이 중 농어목 14 과, 큰가시고기목 3 과로 우점하였다. 과별로는 놀래기과가 7종으로 가장 많은 종수가 출현하였고, 학공 치과 3 종, 촉수과 3 종, 동갈돔과 2종, 자리돔과 2종, 망둑 어과 2종, 꼬치고기과 2종의 순이었다(Table 1).

어종별 출현횟수에서 색줄멸과류 Atherinomrus lacunosus, 학공치과류 Hemiramphus far, 그리고 Strongylura incise 는 17회 출현하여 가장 많았고, 놀래기과류 Halichoeres richmondi는 16회, 청어과 Spratelloides delicatulus는 15 회로 다음 순이었다. 개체수에서 A. lacunosus 가 62.6\% 를 차지하여 최대였고, S. delicatulus 가 $22.4 \%$ 로 다음 순 이었다. 중량에서는 $H . f a r$ 가 $42.1 \%$ 를 차지하여 최대였고, A. lacunosus가 $28.9 \%$ 로 다음 순이었다(Table 2).

\section{월변화}

월별 출현 종수에서 2009년에는 8월에 19종으로 가장 많이 출현하였고, 이후 급격히 줄어드는 경향이었다. 이후 2010년 1-4월에 7-11종이 출현하였고, 5-7월에 1-5종으로

Table 1. The species of fishes caught by the seine net in seagrass bed of Chuuk Lagoon, Micronesia from Aug 2009 to July 2011

\begin{tabular}{llcc}
\hline \multicolumn{1}{c}{ Order } & \multicolumn{1}{c}{ Family } & Genus & Species \\
\hline Clupeiformes & Clupeidae & 1 & 1 \\
Gasterosteiformes & Aulorhynchidae & 1 & 1 \\
& Syngnathidae & 1 & 1 \\
& Fistulariidae & 1 & 1 \\
Atheriniformes & Atherinidae & 1 & 1 \\
Beloniformes & Hemiramphidae & 2 & 3 \\
Perciformes & Apogonidae & 1 & 2 \\
& Carangidae & 1 & 1 \\
& Lethrinidae & 1 & 1 \\
& Mullidae & 2 & 3 \\
& Pomacentridae & 1 & 2 \\
& Labridae & 3 & 7 \\
& Siganidae & 1 & 1 \\
& Acanthuridae & 1 & 1 \\
& Gobiidae & 1 & 2 \\
& Sphyraenidae & 1 & 2 \\
& Bothidae & 1 & 1 \\
& Tetradonidae & 1 & 1 \\
\hline
\end{tabular}

감소하였으며, 8월부터 출현종수가 증가하기 시작하여 12월까지 9-14종의 어류가 출현하였다. 2011년에는 3월에 14종을 제외하여 1-4월 사이에 출현종수가 5-6종으로 적 었고, 5-7월 사이에는 8-13종이 출현하여 2010년과 다소 경향 차이가 있었다(Fig. 3).

월별 출현개체수를 살펴보면 2009년에는 8월과 12월에 각각 739,662 개체로 연중 가장 많은 어류가 출현하였다. 비슷한 경향으로 2010 년에는 9월에 1,644 개체로 연중 가 장 많은 개체수가 출현하였고, 이후 12 월에 884 개체로 다 음 순이었다. 2011년에는 3월에 1,238개체로 연중 가장 많은 수가 채집되었고, 이후 4-7월 사이에 20-356개체 범 위에서 출현개체수 증감이 나타났다(Fig. 3).

생체량은 2009년 8월에 2,379 $\mathrm{g}$ 을 기록한 후 9-11월에 급격히 감소하여 $295-465 \mathrm{~g}$ 의 범위로 조사기간 중 가장 적은 값을 나타내었고, 12 월에 $2,009 \mathrm{~g}$ 으로 증가하였다. 이후 2010년 1-3월에 355-874 g으로 다시 감소하였고, 이 후 증감을 반복하면서 9월에 $7,226 \mathrm{~g}$ 으로 증가하면서 조 사기간 동안 가장 많았으며, 10 월에 $1,492 \mathrm{~g}$ 으로 급격히 감소한 후 12 월에 $3,237 \mathrm{~g}$ 으로 다시 증가하였다. 2011년 에는 1월에 2,035 g을 기록한 후 7월까지 778-4,330 g 범 위에서 증감을 반복하였다(Fig. 3).

종 다양도지수 $\left(\mathrm{H}^{\prime}\right)$ 는 2009년에 9월에 1.67로 연중 가장 높았고, 이후 감소하는 경향이었다. 2010년에는 4월에 1.34 로 연중 가장 높았고, 이후 감소하여 6월에 가장 낮은 값을 기록하였다. 이후 증가하기 시작하여 8월에 1.23 을 기록한 후 다시 감소하였고, 증감을 반복하면서 12 월에 0.64 를 기록하였다. 2011년 1월 0.76에서 증가하기 시작하 여 6월에 2.08로 조사기간 중 가장 높은 값을 기록하였고, 이후 7월에 0.37로 급격히 감소하였다(Fig. 3).

\section{군집분석}

조사기간 동안 3 회 이상 출현한 종을 대상으로 BrayCurtis 유사도 지수를 이용하여 작성된 수상도와 nMDS 결과를 보면 집괴분석에서 유사도 $30 \%$ 수준, 그리고 $\mathrm{nMDS}$ 에서 0.14 강도 수준에서 2 개의 그룹과 3 개체로 구 분되었다(Fig. 4). 1 그룹에는 A. lacunosus, S. delicatulus, 촉수과 Parupeneus barberinus, 실고기과 Syngnathoides biaculeatus, 갈돔과 Lethrinus amboinensis, H. far, S. incise, 놀래기과 Cheilio inermis, Halichoeres richmondi 등이 포함되었다. 2 그룹에는 H. lutkei와 놀래기과 $C$. trilobatus가 포함되었다. 그리고 그룹으로 구분되지 않은 개체들은 실비늘치과 Aeoliscus strigatus, 전갱이과 Caranx sexfasciatus, 놀래기과 H. chloropterus 등이었다(Fig. 4A, B).

어류군집과 환경요인과의 관계를 분석하기 위해 $\mathrm{CCA}$ 를 수행한 결과 성분축, 축 고유값이 각각 $0.323,0.146$ 으 


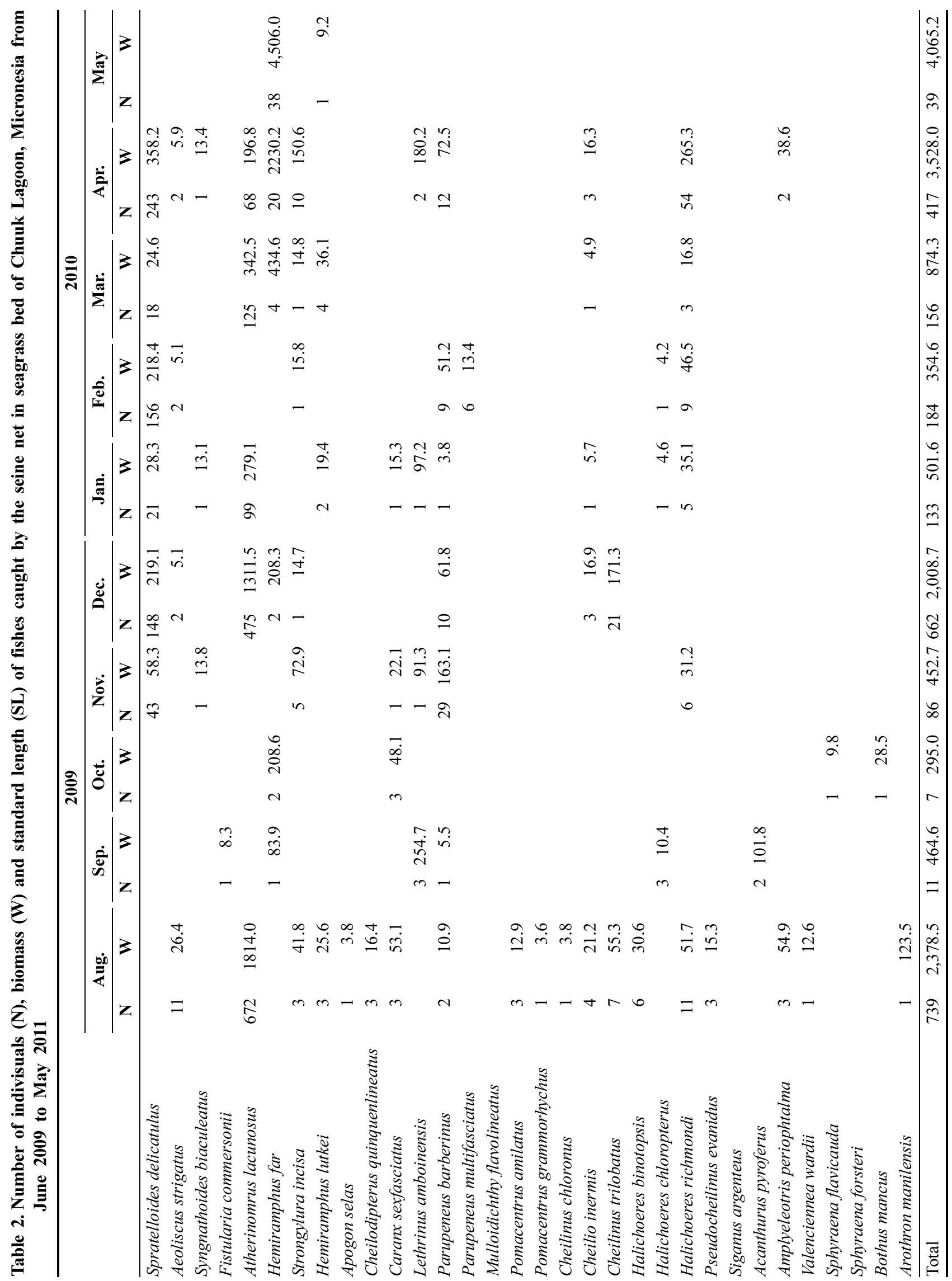




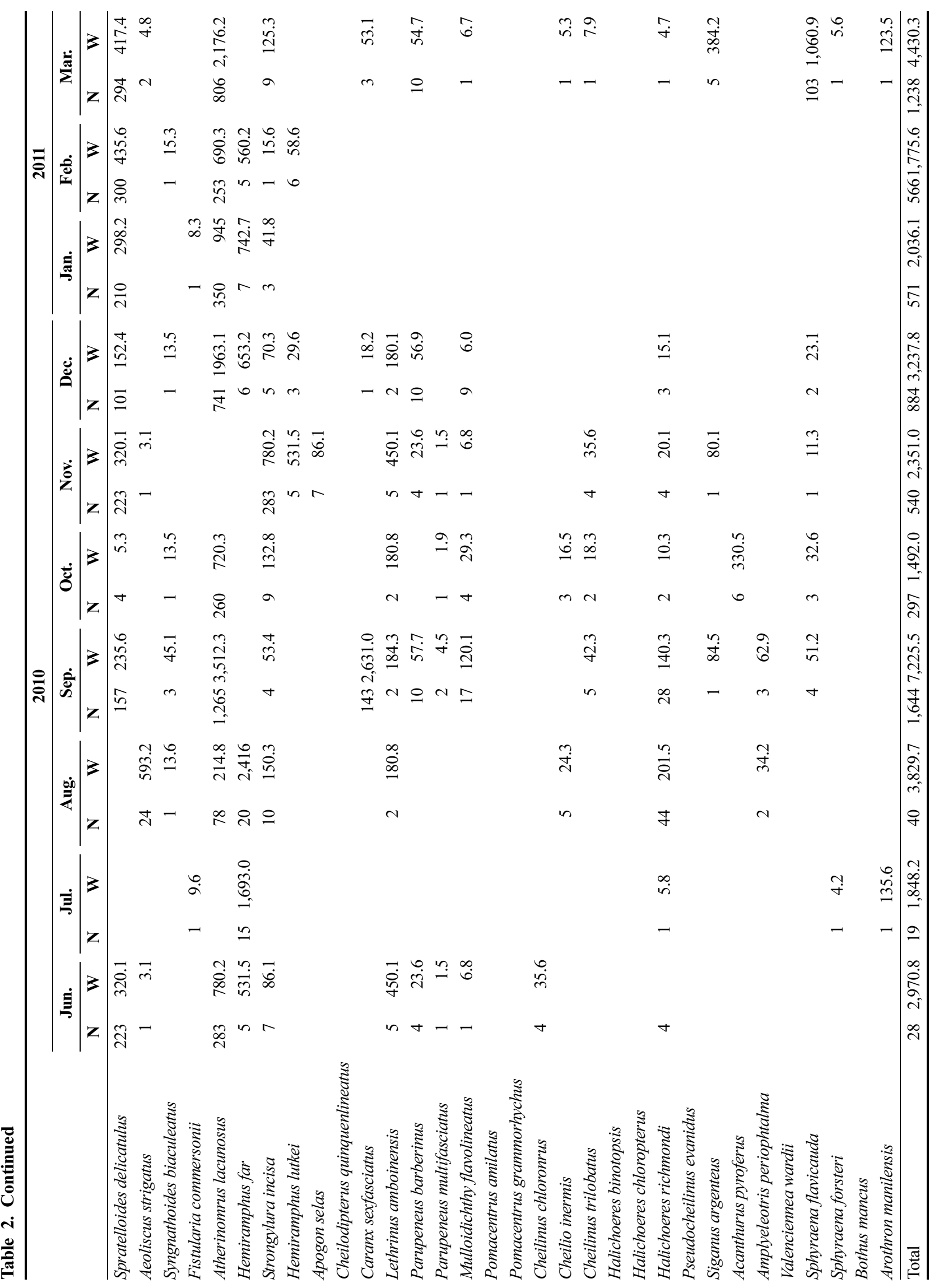




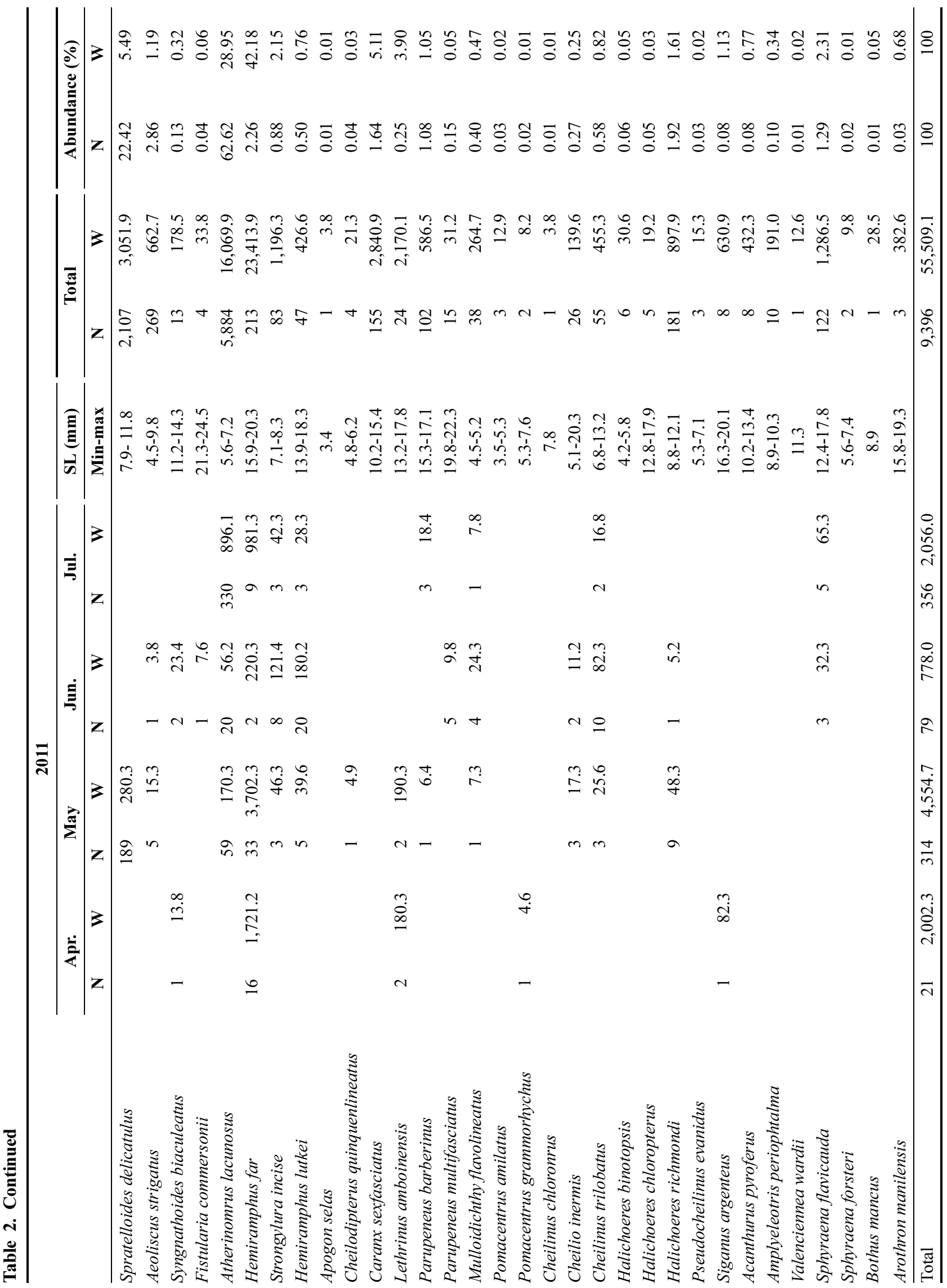



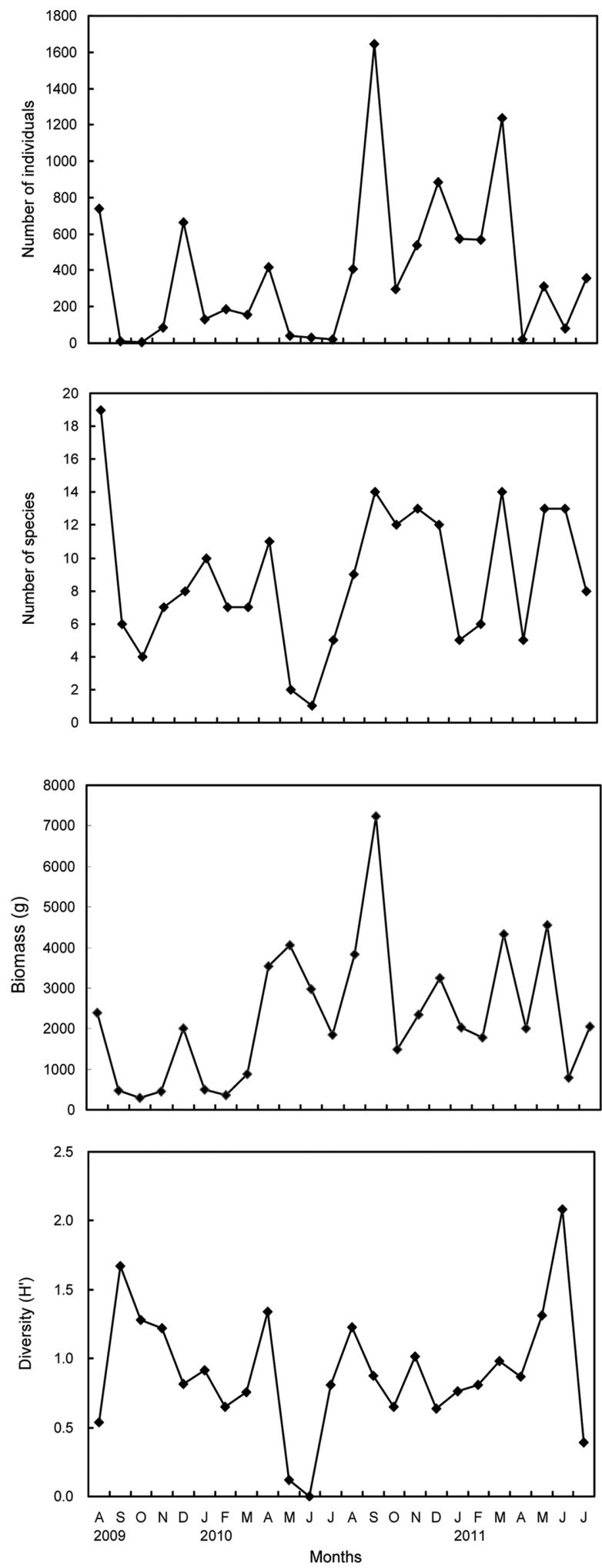

Fig. 3. Monthly variation in number of individuals, number of species, biomass and diversity $\left(\mathrm{H}^{\prime}\right)$ of fishes caught by the seine net in seagrass bed of Chuuk Lagoon, Micronesia from Aug 2009 to July 2011
로 총 분산의 $26.3 \%, 11.9 \%$ 를 차지하여 두 축으로 총 정 보의 $38.2 \%$ 를 나타내었다. H. lutkei, H. far, S. biaculeatus, C, inermis, H. richmondi, S. delicatulus 의 출현은 수온변 화에 영향이 있었다. 그러나 강수량과 어종 출현과의 관계 는 관찰할 수 없었다(Fig. 5).

\section{4. 토 의}

이 연구는 열대연안 잘피밭에서 후릿그물을 사용하여 2009년 8월부터 2011년 7월까지 매월 1회, 총 24회 채집 된 어류를 분석하고, 종조성 및 양적변화를 조사하여 고찰 하고자 한다.

조사기간 동안 총 6 목 18 과 32 종의 어류가 출현하였으 며, 이중 색줄멸과류 Atherinomrus lacunosus와 학공치과 류 Hemiramphus far, Strongylura incise 17회, 놀래기과류 Halichoeres richmondi 16회 그리고 청어과 Spratelloides delicatulus 가 15 회로 가장 많은 출현횟수를 기록하였고, 이들 종은 주요 정착성 어종으로 판단된다. 개체수에서 $A$. lacunosus가 $62.6 \%$ 로 최대였고, S. delicatulus가 $22.4 \%$ 로 다음 순이었다. 이러한 결과는 색줄멸과 어류 A. lacunosus 와 S. delicatulus는 얕은 연안에서 무리를 지어 생활하는 습성을 갖고 있어서(Ivantsoff and Crowley 1999), 잘피밭 에서 채집어구에 대량 포획된 결과로 추정된다. 열대해역 잘피밭 어류 종조사에 관한 선행연구에서 인도네시아 Wakatobi의 잘피밭 3지점에서 Unsworth et al. (2007)은 2개월간 50종을 채집하였고, Blaber et al. (1992)은 오스 트레일리아 북서부 Groote Eylandt의 4지점의 잘피밭에서 2년간 156종, 그리고 아열대해역의 일본 남부 Yaeyama, Okinawa 그리고 Amani 지역 잘피밭 6곳에서 Nakamura and Tsuchiya (2008)는 4개월간 각각 22-27종을 채집하였 다. 선행연구는 이번연구와 채집기간과 채집방법의 차이 는 있지만 어종 출현변화를 고려하여 분기별로 반복조사 하였다는 점에서 방법차이에 따른 직접비교의 어려움은 어느 정도 상쇄될 수 있을 판단된다. 이에 출현종수를 비 교해 보면 이번 연구기간 동안 32 종이 출현하여 인도네시 아, 오스트레일리아의 연안 잘피밭에서 보다는 출현종수 가 적었고, 일본 남부 잘피밭 출현종수 보다는 많았다.

어종의 출현종수는 2009년에는 8월에 19종으로 가장 많았고, 2010년에 8월부터는 출현종수가 증가하여 12월까 지 9-14종의 어류가 출현하여 주로 8월 이후 증가하는 추 세를 보였다. 월별 출현 개체수가 가장 많은 시기는 2009년에 8월과 12월에 그리고 2010년에서 9월과 12월로 종수변화의 양상과 비슷하였다. 생체량은 이 연구기간 동 안 출현어종이 주로 소형이었던 이유에서 출현종수와 개 체수의 증감변화에 다소 차이가 있었다. 그리고 다양성에 서도 2009년 9월, 2010년 4월, 8월 그리고 2011년 6월에 

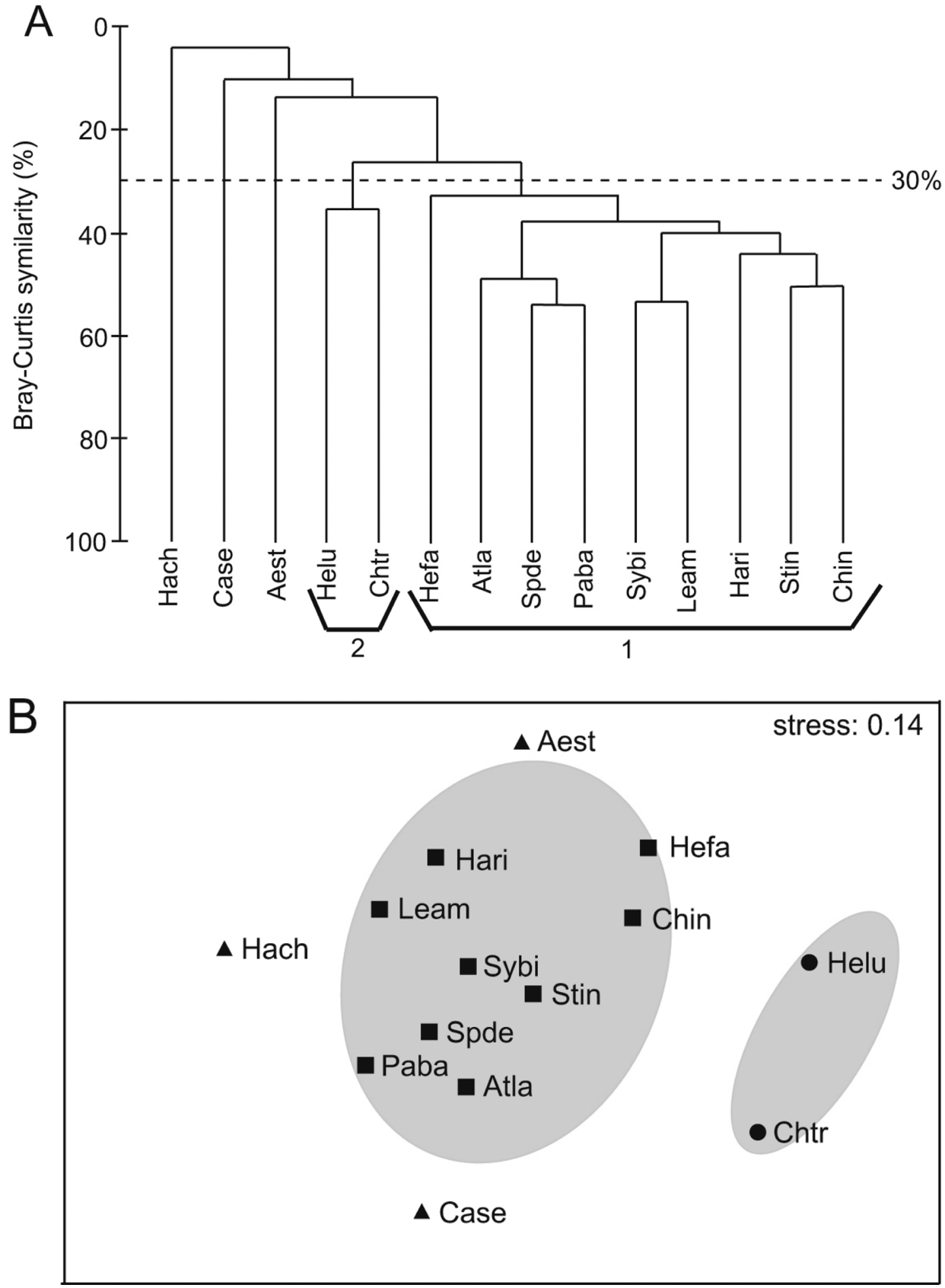

Fig. 4. Dendrogram (A) showing species clustering analysis based on Bray-Curtis similarity matrix of 14 dominant species, and the ordination in 2-dimensions (B) using MDS on the same similarity matrix. Species coded by the first 2 letters of genus and species names

높게 나타나 출현 종수와 개체수의 변화양상과 차이가 있 었다. 이 결과는 이 시기 우점어종 A. lacunosus, S. delicatulus, 그리고 H. far의 출현개체수가 감소하고, 일시 출현종이 다수 출현하면서 다양성이 높아지는 결과를 보 인 것으로 판단된다.

어류의 출현양상에 따라 구분한 결과 1 그룹에서 $A$. lacunosus와 S. delicatulus는 $10 \mathrm{~cm}$ 내외의 크기로 먹이는
동물성 플랑크톤으로 보통 무리를 지어 연안의 모래지역 과 산호초 가장자리 사이를 왕래하며 회유하는 습성을 갖 고 있으며 전 생활사를 잘피밭에서 보내는 어종이다 (Ivanstoff 1984; Lieske and Myers 1994). 이 연구 조사지 역에서 이 두 종은 연중 출현하여 잘피밭을 주 서식지로 이용하고 있는 주거종(resident species)임을 추정할 수 있 었다. 실고기과 Syngnathoides biaculeatus는 이동능력이 


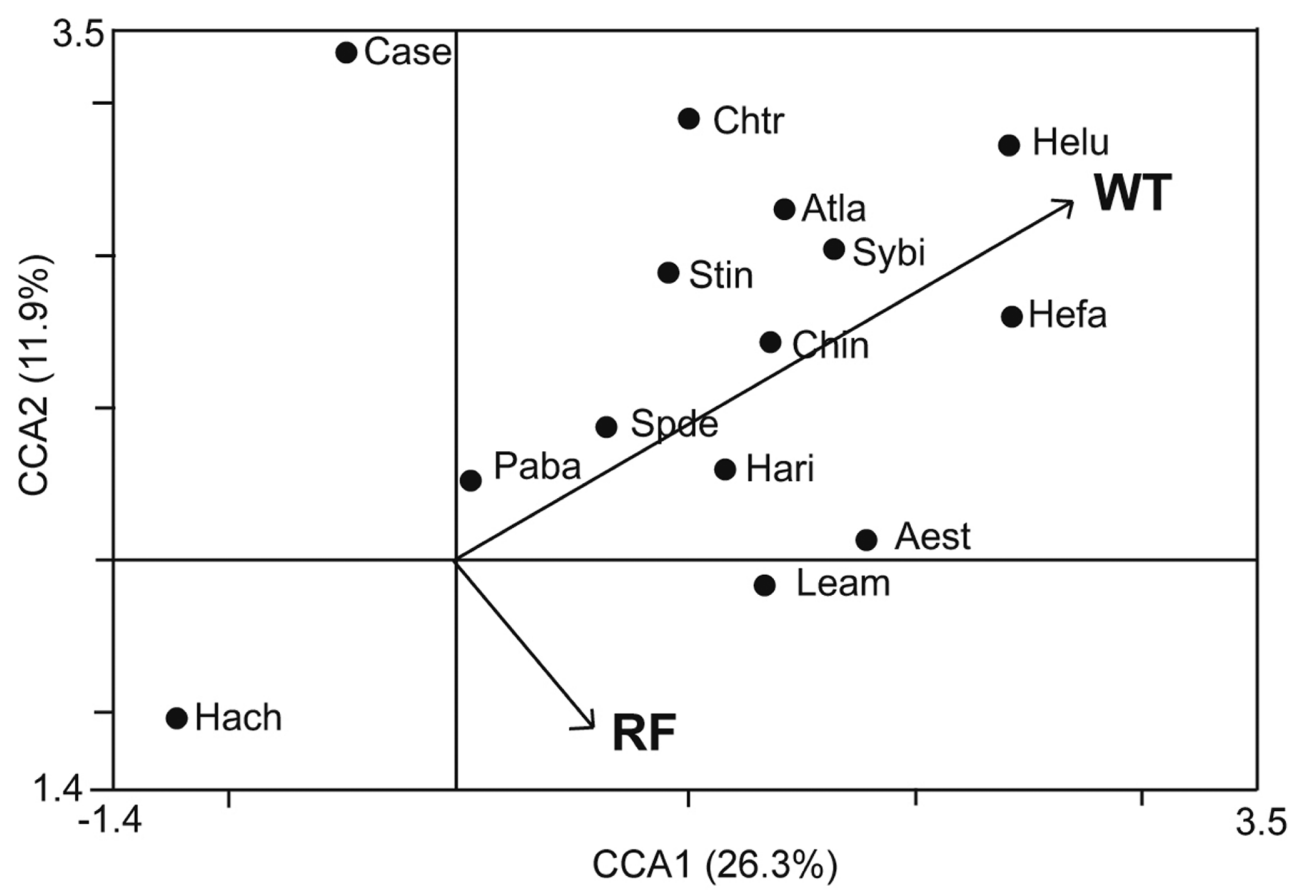

Fig. 5. Canonical Correspondence Analysis (CCA) of 14 dominant species and two environmental parameters. WT: water temperature; RF: rainfall. Species coded by the first 2 letters of genus and species names

약하고 잘피밭에 정주하여 생활하는 대표적인 종으로 서 식지에서 서식밀도가 낮은 것이 특징이다(Kuiter and Tonozuka 2001). 이번 조사에서도 총 10 회 출현하였지만 전 개체수 중 차지하는 비율이 $0.13 \%$ 로 낮게 나타난 것은 이러한 생태학적 특성이 반영된 것으로 판단된다. 갈돔과 Lethrinus amboinensis는 최대 $70 \mathrm{~cm}$ 까지 성장하고, 촉수 과 Parupeneus barberinus 는 $60 \mathrm{~cm}$ 까지, S. incise 그리고 Hemiramphus far는 각각 $100 \mathrm{~cm}$ 와 $45 \mathrm{~cm}$ 까지 성장하는 어종들로 치어기에 앝은 연안에서 생활하다가 성장하면 수심 깊은 산호초 지역으로 이동한다(Myers 1991; Lieske and Myers 1994; Sommer et al. 1996). 이번 조사에서는 L. amboinesis는 체장 $13-17 \mathrm{~cm}, P$. barberinus $15-17 \mathrm{~cm}$, S. incisa 7-8 cm, 그리고 H. far $15-20 \mathrm{~cm}$ 의 치어단계 개 체들이 출현하였다. 이종들은 크기가 커지면서 수심 깊은 산호초 지역으로 이동할 것으로 예상되며, 잘피밭을 치어 의 보육장으로 이용하고 있는 일시 출현종(temporal species)로 추정할 수 있었다. 놀래기과 Cheilio inermis와 Halichoeres richmondi는 잘피밭에서 흔히 발견되는 대표 적인 어종들이다(Myers 1999). 이번 조사에서 이들 종은 $5-20 \mathrm{~cm}$ 의 다양한 크기의 개체가 채집되어 전 생활사를 잘피밭에서 보내는 주거종중에 하나인 것으로 판단된다. 2 그룹에서 학공치과 H. lutkei는 연안의 잘피밭에서 흔히 관찰되는 어종으로 약 $22 \mathrm{~cm}$ 정도이면 최소성숙크기에 이르고, 치어기에는 주로 외해에 떠다니는 유조에서 많이
발견된다(Collete 1999). 그리고 놀래기과 Cheilinus trilobatus는 환초내 잘피밭 그리고 산호초 지역에서 볼 수 있는 종이다(Lieske and Myers 1994). 이에 이 두 종은 생 활단계에 따라 일시적으로 출현한 종으로 판단된다. 그리 고 주요 어종 중 그룹에 속하지 않고 개체로 구분된 실비 늘치과 Aeoliscus strigatus는 열대 잘피밭에서 발견되는 주요 어종 중 하나로서 몸을 수직으로 세워 유영하는 습 성을 지니고, 이동능력이 낮으며, 주로 동물성 플랑크톤이 나 소형 갑각류를 먹고 생활한다(Myers 1999). 이번 조사 에서는 총 9 회 출현하였고, 종종 산호초 주변에서 관찰되 는 경우에 비추어 잘피밭과 산호초 사이를 이동하며 생활 하는 종 중에 하나인 것으로 판단된다. 전갱이과 Caranx sexfasciatus는 최대 $120 \mathrm{~cm}$ 까지 성장하고, 수심 $70 \mathrm{~m}$ 전 후의 환경에서 무리를 지어 생활하는 어종이다(Myers 1999). 이번 조사에서 이종은 $10-15 \mathrm{~cm}$ 범위의 치어단계 의 개체들이 채집되어 일시적으로 출현한 일시출현종으로 판단되며, 잘피밭을 보육장으로 이용하고 있음을 추정할 수 있었다. 그리고 놀래기과 H. chloropterus는 주로 얕은 연안의 산호초 지대와 죽은 산호 덤불 사이에 서식하는 종이다(Randall et al. 1990). 이 연구에서 3회 출현하였고, 일시적으로 출현한 종으로 추정된다.

연안해역에서 강수량, 수온등과 같은 환경요인의 변화 는 종조성과 어획량에 영향을 미친다(Chen et al. 1994; Meynecke et al. 2006; Wen and Sidik 2011). 선행연구에 
서 Meyneck et al. (2006)은 오스트레일리아 Moreton Bay 에서 1988-2004년 동안 어획량이 연도별 700-1,600 mm 의 강수량 변화와 밀접한 상관관계가 있었다고 보고하였 다. 말레이시아 Sabah 연안해역에서 2000-2009년 사이의 어류 어획량은 월별 $0-600 \mathrm{~mm}$ 의 강수량 변화와 $26-28.5^{\circ} \mathrm{C}$ 의 수온변화로부터 영향이 있었음을 보고한 바 있다(Wen and Sidik 2011). 이처럼 강수량과 어류어획량과의 상관성 은 강수량변화에 따라 육지로부터 연안해역으로 이동시키 는 영양물질의 양에 따라 먹이원 양도 변화되는 결과에 따른 것이다(Aleem 1972; Kramer 1978; Salen-Picard et al. 2002). 또한 수온변화는 열대연안에서 급격하게 일어 나지 않지만 작은 증감으로 해황에 영향을 줄 수 있다 (Wen and Sidik 2011). 이번 연구 해역이 육지와의 거리가 $300 \mathrm{~m}$ 이내이고, 수심이 $1 \mathrm{~m}$ 내외인 잘피밭인 것을 감안 하면 조사기간 동안 $62.5-645.9 \mathrm{~mm}$ 의 강수량 변화와 28.3-29.7 ${ }^{\circ} \mathrm{C}$ 수온변화가 어류출현양상에 영향을 미칠 것 으로 예상되었다. 그러나 주요어종 14 종과 환경과의 $\mathrm{CCA}$ 수행한 결과 H. lutkei, H. far, S. biaculeatus, C. inermis, $H$. richmondi, 그리고 $S$. delicatuluse 등 일부 종의 출현양상 에서 수온과의 관계를 관찰할 수 있었다. 향후, 열대해역 에서 해황 변동을 고려한 종 출현경향을 보다 잘 이해하 기 위해서는 해류, 조석, 염분 등의 물리화학적 환경영향 을 고려한 조사가 더 진행되어야 할 것으로 생각된다.

이상과 같이 마이크로네시아 축의 잘피밭에는 얕은 연 안에서 무리생활을 하고, 주 서식지로 일생을 잘피밭에서 보내는 주거종과 생활사 단계에 따라 치어기에 일시적으 로 잘피밭을 보육장으로 이용하면서 머물고 있는 일시출 현종이 혼재하고 있었다. 이번 조사결과, 어류군집에 있어 서 맹그로브와 산호초 군락사이의 이행대에 위치한 잘피 밭의 역할을 명확하게 이해하기에는 어려움이 있었다. 따 라서 잘피밭에서 관찰된 어류를 중심으로 산호초, 맹그로 브 군락에서 연계적으로 출현양상을 조사해 볼 필요가 있 을 것으로 생각된다.

\section{사 사}

이 연구는 “적도태평양 연구인프라 구축 사업(PE98962)" 및 “열대 태평양기지 자원생물 생산 및 기본연구활동 지 원(PE99161)"의 지원으로 수행되었습니다.

\section{참고문헌}

Adams AJ, Dahlgren CP, Todd Kellison G, Kendall MS, Layman CA, Ley JA, Nagelkerken I, Serafy JE (2006) Nursery function of tropical back-reef systems. Mar Ecol Prog Ser 318:287-301
Aleem AA (1972) Effect of river outflow management on marine life. Mar Biol 15:200-208

Bell JD, Pollard DA (1989) Ecology of fish assemblages and fisheries accociated with seagrasses. In: McComb AJ, Larkum AWD, Shepherd SA (eds) The biology of seagrasses: an Australian perspective. Elsevier, Amsterdam, pp 565-609

Blaber SJD, Brewer DT, Salini JP, Kerr JD, Conacher C (1992) Species composition and biomasses of fishes in tropical seagrasses at Groote Eylandt, northern Australia. Estuar Coast Shelf Sci 35:605-620

Chen YL, Chen HY, Tzeng WN (1994) Reappraisal of the importance of rainfall in affecting catches of Anguillia japonica Elvers in Taiwan. Aust J Mar Fresh Res 45:185-190

Collete BB (1999) Hemiramphidae. In: Carpenter KE, Niem $\mathrm{V}$ (eds) FAO species identification guide for fishery purposes. The living marine resources of the Western Central Pacific. FAO, Rome, pp 2180-2196

Guidetti P, Bussotti S (2002) Effects of seagrass canopy removal on fish in shallow Mediterranean seagrass (Cymodocea nodosa and Zostera noltii) meadows: a local-scale approach. Mar Biol 140:445-453

Ivanstoff W (1984) Atherinidae. In: Fischer W, Bianchi G (eds) FAO species identification sheets for fishery purposes. FAO, Rome, pp 118

Ivanstoff W, Crowley LELM (1999) Atherinidae. Silversides (or hardyheads). In: Carpenter KE, Niem VH (eds) FAO species identification guide for fishery purposes. The living marine resources of the Western Central Pacific. FAO, Rome, pp 2113-2139

Klumpp DW, Bayne BL, Hawkins AJS (1992) Nutrition of the giant clam Tridacna gigas (L.). Contributions of filter feeding and photosynthesis to respiration and growth. J Exp Mar Biol Ecol 155:105-122

Kramer DL (1978) Reproductive seasonality in the fishes of a tropical stream. Ecology 59(5):976-985

Kwak SN, Klumpp DW (2004) Temporal variation in species composition and abundance of fish and decapods of a tropical seagrass bed in Cockle Bay, North Queensland, Australia. Aquat Bot 78:119-134

Kuiter RH, Tonozuka T (2001) Pictorial guide to Indonesian reef fishes. Part 1. Eels-Snappers, Muraenidae-Lutjanidae. Zoonetics, Australia, $302 \mathrm{p}$

Lieske E, Myers R (1994) Coral reef fishes: Indo-Pacific \& Caribbean including the Red Sea. (Collins Pocket Guide.) Haper Collins Publishers, New York, 400 p

Livingstone RJ (1984) The relationship of physical factors and biological response in coastal seagrass meadows. 
Estuaries 7:377-390

Meynecke JO, Lee SY, Duck NC, Warnken J (2006) Effects of rainfall as a component of climate change on estuarine fish production in Queensland, Australia. Estuar Coast Shelf Sci 69:491-504

Myers RF (1999) Micronesian Reef Fishes: A Field Guide for Divers and Aquarists. Coral Graphics, Guam, $216 \mathrm{p}$

Nakamura Y, Tsuchiya M (2008) Spatial and temporal patterns of seagrass habitat use by fishes at the Ryukyu Islands, Japan. Estuar Coast Shelf Sci 76:345-356

NOAA (2013) National Oceanic and Atmospheric Administration. http://www.prh.noaa.gov/peac/update.php/Accessed 20 July 2013

Parrish JD (1989) Fish communities of interacting shallowwater habitats in tropical ocean regions. Mar Ecol Prog Ser 58:143-160

Randall JE, Allen GR, Steene RC (1990) Fishes of the Great Barrier Reef and Coral Sea. University of Hawaii Press, Honolulu, Hawaii, 506 p

Salen-Picard C, Darnaude AM, Arlhac AM, Harmelin-Viven ML (2002) Fluctuations of macrobentic populations: a link between climate-driven river run-off and sole fishery yield in the Gulf of Lions. Oecologia 133:380-388

Shannon CE, Wiener W (1963) The Mathematical Theory of Community. University of Illinois Press, Urbana, $125 \mathrm{p}$

Sommer C, Schneider W, Poutiers JM (1996) FAO species identification field guide for fishery purposes. The living marine resources of Somalia. FAO, Rome, $376 \mathrm{p}$

Stoner AW (1980) Feeding ecology of Lagodon rhomboides (Pisces: Sparidae): Variation and functional response. Fish B-Noaa 78(2):337-352

Thayer GW, Bjorndal KA, Ogden JC, Williams SL, Zieman JC (1984) Role of larger herbivores in seagrass communities. Estuaries 4:351-376

Unsworth RKF, Bell JJ, Smith DJ (2007) Tidal fish connectivity of reef and seagrass habitats in the IndoPacific. J Mar Biol Assoc Uk 37:1287-1296

Wen PP, Sidik MJ (2011) Impacts of rainfall, temperature and recent El Niño on fisheries and agricultural products in the west coast of Sabah. Bor Sci 28:73-85 